\title{
Etiology of ambiguous genitalia in newborns with XX karyotype: A cross-sectional observational study.
}

1. MBBS, DCH, FCPS Associate Professor Pediatric Endocrinology

2. MBBS, DCH, FCPS (Pediatrics), FCPS (Neonatology) Assistant Professor Neonatology

3. MBBS, MCPS (Pediatrics) FCPS (Pediatrics)

Assistant Professor Developmenta Pediatrics

4. MBBS, FCPS (Pediatrics) Associate Professor Pediatrics

5. MBBS, FCPS (Pediatrics) Women Medical Officer

6. MBBS

Post Graduate Resident

$1,2,3,4,5,6$

The Children Hospital and

Institute of Child Health Multan.

Correspondence Address:

Dr. Waqas Imran Khan

Department of Pediatric Endocrinology

The Children Hospital and

Institute of Child Health Multan.

drwaqas69@hotmail.com

Article received on:

06/08/2020

Accepted for publication:

$18 / 12 / 2020$

\section{INTRODUCTION}

Disorders of sex development (DSD) are characterized as inherent conditions in which development of sex of an individual is unusual. ${ }^{1}$ A few newborns are born into this world with ambiguous genitalia. This implies that the visible genitals - penis and testes or vagina and clitoris-aren't obviously either male or female. This condition occurs roughly once in every 4,500 births $^{2}$ in countries like Saudi Arabia and Egypt where there is high rate of consanguinity. On the other hand, its prevalence as reported in Germany is low, i.e. once in every 10,000 births. ${ }^{3}$

At origination, determination of sex depends on chromosomes that are inherited from their parents. An individual is considered as female having $X X$ karyotype, on the other hand an $X Y$ karyotype as male. After fertilization of an ovum the sex of an individual is determined long before the gonads are developing. Ambiguous genitalia can develop if hormones controlling this process are disturbed. ${ }^{4,5}$

Neonatal genital ambiguity needs widespread and urgent investigations for critical disorder like congenital adrenal hyperplasia $(\mathrm{CAH})$ which is a frequent cause of DSD. ${ }^{6,7}$ Aromatase insufficiency, intake of androgens or progestins, virilizing adrenal and ovarian tumors, or luteomas are infrequent causes of ambiguous genitalia. Lastly, ovotesticular and 46, XX testicular DSD are seen.

Extensive clinical, hormonal, radiological, chromosomal, and genetic evaluations are hence required. However, for precise diagnosis and treatment an urgent evaluation is needed with high index of suspicion about life threatening 
condition like $\mathrm{CAH}$. Satisfactory management and prompt gender assignment will have a good impact on psychosocial wellbeing of parents. ${ }^{8,9}$ As they have a key role is decision making process they should be involved in each step of diagnosis and treatment.

The objective of my research is to determine the etiology of ambiguous genitalia in newborn females with XX karyotype.

\section{MATERIAL \& METHODS}

This cross sectional observational study was completed in department of pediatric endocrinology and neonatology at The Children hospital \& the Institute of Child health Multan (CH\& ICH) from July 2018 to December 2019. Fifty two patients were enrolled after taking informed consent from parents/guardians, according to following criteria: newborn babies that presents within the first 28 days of life and Karyotype proven XX females that are clinically diagnosed of having ambiguous genitalia. All the cases aged more than 28 days, as well as having normal genitalia or those having palpable gonads and not giving consent to participate in this study by patient's/guardians were excluded from this study.

The obstetric history included any endocrine problem in mother (Cushingoid features or virilization), or use of medications for recurrent abortion or contraceptive pills). As some of the causes of DSD are recessively inherited, family histories of genital anomalies, neonatal deaths, atypical pubertal development, or infertility were specifically asked. A complete physical examination of the baby was done to assess for any dysmorphic features. The genital examination included localization of gonads, size of clitoris, urethral opening and vaginal adhesions. Pelvic ultrasonography for internal genital organs, karyotyping, serum electrolytes, hormonal levels both basal and ACTH stimulated (17 hydroxy progesterone, plasma rennin testosterone and dehydroepiandrosterone sulphate-DHEAS) were done. All the data was noted on a predesigned Performa.
Data was entertained in SPSS version 20 for analysis. Quantitative variables are represented as mean and standard deviation. Qualitative variables are represented as frequencies and percentages i.e. causes of ambiguous genitalia in the newborn XX females. These causes include congenital adrenal hyperplasia, maternal intake of virilizing drugs during pregnancy and isolated local genital defect. The effect modifiers like environmental exposure to drugs, congenital deficiency of an enzyme and genetic defect causing gross dysmorphism were controlled by stratification of data. Chi square test was applied to find relationship of causes of ambiguous genitalia with weight and gestational age of study subjects. $P$ value $\leq 0.05$ is taken as significant. This study was affirmed by the institutional Ethical committee of $\mathrm{CH} \& \mathrm{ICH}$, Multan.

\section{RESULTS}

A total of 52 patients were enrolled in this study. Table-I shows mean gestational age of $38.23 \pm$ 2.36 weeks and $10(20.2 \%)$ had gestational age up to 36 weeks while $42(80.8 \%)$ had gestational age more than 36 weeks. Mean age was $12.37 \pm$ 4.21 days and age range was 3-24 days. Mean weight was $2965.43 \pm 412.23$ grams while 24 (46.1\%) had weight up to 2500 grams and 28 (53.9\%) had weight more than 2500 grams.

Table-Il shows various causes of ambiguous genitalia. CAH in our study cases was noted in 45 (86.5\%). Congenital local genital defects in our study cases were noted in 6 (11.5\%) while maternal ingestion of virilizing drugs during pregnancy was noted in 1 (2\%) of our study cases. These causes of ambiguous genitalia were stratified with regards to gestational age, weight. (Table-III).

\begin{tabular}{|l|c|}
\hline \multicolumn{1}{|c|}{ Mean Age } & $\mathbf{1 2 . 3 7} \pm \mathbf{4 . 2 1}$ days \\
\hline Range & $3-24$ days \\
\hline $\begin{array}{c}\text { Gestational age } \\
\leq 36 \text { weeks } \\
>36 \text { weeks }\end{array}$ & $10(20.2 \%)$ \\
\hline $\begin{array}{l}\text { Weight } \\
\leq 2500 \text { grams } \\
>2500 \mathrm{gm}\end{array}$ & $42(80.8 \%)$ \\
\hline
\end{tabular}

Table-I. Descriptive statistics of study cases $(n=52)$. 


\begin{tabular}{|l|c|}
\hline CAH & $45(86.5 \%)$ \\
\hline Local genital defects & $6(11.5 \%)$ \\
\hline Maternal ingestion of virilizing drugs during pregnancy & $1(2 \%)$ \\
\hline \multicolumn{2}{|r|}{} \\
\hline
\end{tabular}

\begin{tabular}{|c|c|c|c|c|c|c|c|c|c|c|}
\hline \multirow[t]{2}{*}{$\mathrm{N}-52$} & \multicolumn{2}{|c|}{ CAH } & \multirow[t]{2}{*}{ Total } & \multicolumn{2}{|c|}{$\begin{array}{l}\text { Local Genital } \\
\text { Defects }\end{array}$} & \multirow[t]{2}{*}{ Total } & \multicolumn{2}{|c|}{$\begin{array}{l}\text { Virilizing Drug } \\
\text { Ingestion }\end{array}$} & \multirow[t]{2}{*}{ Total } & \multirow[t]{2}{*}{ P-Value } \\
\hline & Yes & No & & Yes & No & & Yes & No & & \\
\hline $\begin{array}{c}\text { Gestational age } \\
\leq 36 \text { weeks } \\
>36 \text { weeks }\end{array}$ & $\begin{array}{l}12 \\
33\end{array}$ & $\begin{array}{l}2 \\
5\end{array}$ & $\begin{array}{l}14 \\
38\end{array}$ & $\begin{array}{l}02 \\
04\end{array}$ & $\begin{array}{l}14 \\
32\end{array}$ & $\begin{array}{l}16 \\
36\end{array}$ & $\begin{array}{l}1 \\
0\end{array}$ & $\begin{array}{l}15 \\
36\end{array}$ & $\begin{array}{l}16 \\
36\end{array}$ & 0.680 \\
\hline $\begin{array}{l}\text { weight } \\
\leq 2500 \text { Grams } \\
>2500 \text { Grams }\end{array}$ & $\begin{array}{l}22 \\
23\end{array}$ & $\begin{array}{l}5 \\
4\end{array}$ & $\begin{array}{l}27 \\
27\end{array}$ & $\begin{array}{l}01 \\
05\end{array}$ & $\begin{array}{l}18 \\
28\end{array}$ & $\begin{array}{l}19 \\
33\end{array}$ & $\begin{array}{l}0 \\
1\end{array}$ & $\begin{array}{l}23 \\
28\end{array}$ & $\begin{array}{l}23 \\
29\end{array}$ & 0.595 \\
\hline
\end{tabular}

\section{DISCUSSION}

At the time of fertilization the genetic sex of a person is determined. Accordingly a 46XX karyotype would form into a phenotypic female, and $46 \mathrm{XY}$ to a phenotypic male embryo. DSD develop because of a dissimilarity between the genetic, gonadal and phenotypic sex and are the outcome of early disorder in the programming of sex determination. ${ }^{10,11}$ One of clinical emergencies in infants with genital ambiguity, for example $\mathrm{CAH}^{12}$ and certain dysmorphic syndromes which may be life threatening to child's life, and uncertain sex may cause devastating psychosocial impacts on patients and parents. A skilled multidisciplinary team ${ }^{13,14}$ is necessary for the comprehensive care of kids with ambiguous genitalia which is typically found in teaching hospitals.

In our study the most frequent reason of ambiguous genitalia is CAH $45(86.5 \%)$. These results are similar to a study done in Syria which also showed high rate of $\mathrm{CAH}$ in ambiguous genitalia. ${ }^{15}$ Congenital local genital defects in our study cases were noted in $6(11.5 \%)$ while maternal ingestion of virilizing drugs during pregnancy was noted in $1(2 \%)$ of our study cases. Literature review also suggests that $\mathrm{CAH}$ is the most frequent reason of ambiguous genitalia with XX karyotype. ${ }^{16,17}$ Similar findings are seen in present study that $86.5 \%$ of cases were $\mathrm{CAH}$.

$\mathrm{CAH}$ was not associated with gestational age or weight of newborn with $p$ value 0.680 and 0.595 respectively. Similar results were also observed in congenital local defects and maternal intake of virilizing drugs. Poyrazoglu S. et al ${ }^{18}$ and Miles HL et al. ${ }^{19}$ also reported no association of birth weight with various causes of ambiguous genitalia.

In countries like Pakistan with meager resources prompt diagnosis and management of ambiguous genitalia is warranted to avoid life threatening complication of $\mathrm{CAH}$ and psyclogical support for the family. High risk families should be offered prenatal testing and antenatal treatment to avoid genital ambiguity. Development of specialized centers and trained staff with expertise in dealing with disorders of sexual differentiation is essential for caring such patients. The limitations of my study are small number of patients as this is a rare condition. Due to rapidly evolving genetic testing, new technology should be incorporated in the diagnostic procedure. Due to diversity of causes of ambiguous genitalia the subgroups are small but it shows the challenge of diagnosing such children.

\section{CONCLUSION}

Congenital adrenal hyperplasia in our study cases was the most commonest reason of ambiguous genitalia in newborn females with XX karyotype followed by congenital local defects and maternal use of virilizing drugs. High index of suspicion is required for the diagnosis of potential life 
threatening disorder like $\mathrm{CAH}$.

Copyright $@ 18$ Dec, 2020.

\section{REFERENCES}

1. Lee PA, Houk CP, Ahmed SF, Hughes IA. Consensus statement on management of intersex disorder. International consensus conference on intersex. Pediatrics. 2006; 118(2):488-500. doi: 10.1542/ peds.2006-0738.

2. Mulhim, Kamal HM. Ambiguous genitalia in neonates: A 4-year prospective study in a localized area. East Mediterr Health J. 2010; 16(2).

3. Thyen U, Lanz K, Holterhus PM, Hiort O. Epidemiology and initial management of ambiguous genitalia at birth in Germany. Horm Res. 2006; 66(4):195-203. doi: 10.1159/000094782.

4. Yamada H, Takeda T, Koga T. Role of the critical period in sex and brain differentiation. 2014; 134(4):529-35.

5. Ocal G. Current concepts in disorders of sexual development. J Clin Res Pediatr Endocrinol. 2011; 3(3):105-14.

6. Speiser PW, Azziz R, Baskin LS, Ghizzoni L, Hensle TW, Merke DP, et al. Congenital adrenal hyperplasia due to steroid 21- hydroxylase deficiency: An endocrine society clinical practice guideline. J Clin Endocrinol Metab. 2010; 95(9):4133-4160. doi: 10.1210/jc.20092631.

7. Al-Mutair A, lqbal MA, Sakati N, Ashwal A. Cytogenetics and etiology of ambiguous genitalia in 120 pediatric patients. Ann Saudi Med. 2004; 24(5):368-372. doi: 10.5144/0256-4947.2004.368.

8. Slijper FM, Drop SL, Molenaar JC, de Muinck KeizerSchrama SM. Long-term psychological evaluation of intersex children. Arch Sex Behav. 1998; 27(2):125144.

9. Sultan C, Paris F, Jeandel C, Lumbroso S, Galifer RB. Ambiguous genitalia in the newborn. Semin Reprod Med. 2002; 20(3):181-188. doi: 10.1055/s-2002-35382.
10. Chowdhury MAK, Anwar R, Saha A. Ambiguous genitalia-A social dilemma in Bangladesh: $A$ case report. Int J Surg Case Rep. 2018; 42:98-101.

11. Zdravković $D^{1}$, Milenković T, Sedlecki K, Guć-Sćekić M, Rajić V, Banićević M. Causes of ambiguous external genitalia in neonates. Srp Arh Celok Lek. 2001 MarApr; 129(3-4):57-60.

12. Joshi RR, Rao S, Desai M. Etiology and clinical profile of ambiguous genitalia. An overview of 10 years experience. Indian Pediatr. 2006; 43(11):974-979.

13. Ogilvy-Stuart AL, Brain CE. Early assessment of ambiguous genitalia. Arch Dis Child. 2004; 89(5):401407. doi: 10.1136/adc.2002.011312.

14. De Paula GB, Barros BA, Carpini S, Tincani BJ, Mazzola TN, et al: 408 cases of genital ambiguity followed by single multidisciplinary team during 23 years: Etiologic diagnosis and sex of rearing. Int $\mathrm{J}$ Endocrinol 2016: 4963574.

15. Al-Jurayyan NA. Ambiguous genitalia: Two decades of experience. Ann Saudi Med. 2011; 31(3):284-288. doi:10.4103/0256-4947.81544.

16. Lambert SM, Vilain EJN, Kolon TF. A practical approach to ambiguous genitalia in the newborn period. Urol Clin N Am. 2010; 37:195-205. doi: 10.1016/j. ucl.2010.03.014.

17. Walia R, Singla M, Vaiphei K, Kumar S, Bhansali A. Disorders of sex development: A study of 194 cases. Endocr Connect. 2018; 7:364-71.

18. Poyrazoglu S, Darendeliler F, Ahmed SF, Hughes I, Bryce $\mathrm{J}$, Jiang $\mathrm{J}$, et. al Birth weight in different etiologies of disorders of sex development. J Clin Endocrinol Metab. 2017; 102(3):1044-1050.

19. Miles HL, Gidl" of S, Nordenstr" om A, Ong KK, Hughes IA. The role of androgens in fetal growth: Observational study in two genetic models of disordered androgen signalling. Arch Dis Child Fetal Neonatal Ed. 2010; 95(6):F435-F438. 


\section{AUTHORSHIP AND CONTRIBUTION DECLARATION}

\begin{tabular}{|c|c|c|c|}
\hline Sr. \# & Author(s) Full Name & Contribution to the paper & Author(s) Signature \\
\hline 1 & Waqas Imran Khan & $\begin{array}{l}\text { Literature search, Study design, Data } \\
\text { acquisition, review, final approval. }\end{array}$ & \\
\hline 2 & Abdur Rehman & $\begin{array}{l}\text { Data acquisition, Critical review, } \\
\text { Approval. }\end{array}$ & ef. Cun \\
\hline 3 & Erum Afzal & $\begin{array}{l}\text { Data acquisition, Critical review, } \\
\text { Approval. }\end{array}$ & A \\
\hline 4 & Asim Khurshid & $\begin{array}{l}\text { Data acquisition, Critical review, } \\
\text { Approval. }\end{array}$ & \\
\hline 5 & Sidra Anjum & $\begin{array}{l}\text { Data acquisition, Critical review, } \\
\text { Approval. }\end{array}$ & Sidns. \\
\hline 6 & Fazal ur Rehman & $\begin{array}{l}\text { Data acquisition, Critical review, } \\
\text { Approval. }\end{array}$ & Haglu-velima. \\
\hline
\end{tabular}

